\title{
Respiration rate and its effect on mass loss and chemical qualities of 'Fuyu' persimmon fruit stored in controlled atmosphere
}

\author{
Taxa respiratória e seu efeito na perda de massa e qualidades químicas de caqui 'Fuyu' \\ armazenado em atmosfera controlada
}

\author{
Auri Brackmann ${ }^{\mathrm{I}}$ Fabio Rodrigo Thewes ${ }^{\mathrm{II}}$ Rogério de Oliveira Anese ${ }^{\mathrm{III}}$ Vanderlei Both ${ }^{\mathrm{IV}}$ \\ Adriano Roque de Gasperin ${ }^{\mathrm{V}}$
}

- NOTE -

ABSTRACT

The objective of this research was evaluate the effect of two $\mathrm{CO}_{2}$ partial pressures in ultra-low oxygen on the mass loss in function of respiration, oxygen consumption, respiratory rate and other characteristics of 'Fuyu' persimmon during 12 weeks in controlled atmosphere (CA) storage at temperature of $-0,5^{\circ} \mathrm{C}$. For thus, one experiment was carried out with the followed $C A$ condition: [1] $0.15 \mathrm{kPa} \mathrm{O}_{2}$ plus $2.0 \mathrm{kPa} \mathrm{CO}_{2}$ and [2] $0.15 \mathrm{kPaO}$ plus $6.0 \mathrm{kPa} \mathrm{CO}$. On this study was verified that the respiration (carbon dioxide production) was responsible for $24 \%$ of total mass loss. The total mass loss is significantly affected by the controlled atmosphere storage. The $2.0 \mathrm{kPaCO}$ promotes changes in the respiratory quotient during the storage period and keep higher mass loss in function of respiration ( $\mathrm{CO}_{2}$ losses) and lower soluble solids after storage.

Key words: Diospyrus kaki, postharvest, oxygen uptake, $\mathrm{CO}_{2}$ losses, soluble solids.

\section{RESUMO}

O objetivo deste trabalho foi avaliar o efeito de duas pressões parciais de $\mathrm{CO}_{2}$ em ultrabaixo oxigênio sobre a perda de massa em função da respiração, consumo de $\mathrm{O}_{2}$, taxa respiratória e outras características de caqui 'Fuyu', durante 12 semanas de armazenamento, em atmosfera controlada na temperatura de $-0,5^{\circ} \mathrm{C}$. Para tanto, um experimento foi conduzido com as seguintes condições de AC: [1] 0,15 kPa O mais 2,0 kPa CO e [2] 0,15 kPa $\mathrm{O}_{2}$ mais $6,0 \mathrm{kPa} \mathrm{CO}$. A respiração (produção de gás carbônico) foi responsável por $24 \%$ do total de perda de massa. A perda de massa é significativamente afetada pelas condições de atmosfera controlada. 2,0 $\mathrm{kPa} \mathrm{CO}_{2}$ promove mudanças no quociente respiratório durante o armazenamento, proporciona maior perda de massa em função da respiração e menor concentração de sólidos solúveis depois do armazenamento.

Palavras-chave: Diospyrus kaki, pós-colheita, consumo de oxigênio, perda de $\mathrm{CO}_{2}$, sólidos solúveis.

During storage time, one of the most important events of fruit is the respiration, where oxygen $\left(\mathrm{O}_{2}\right)$ uptake and carbon dioxide $\left(\mathrm{CO}_{2}\right)$ production occurs at the same scale, in aerobic conditions (STEFFENS et al., 2007). With the respiration process occurs soluble solids and titratable acidity consumption. The decrease in respiratory rates during Postharvest life of the fruit can be achieved by reducing the temperature and use of controlled atmosphere storage (STEFFENS et al., 2007; BRACKMANN et al., 2008). Throughout the storage, $\mathrm{CO}_{2}$ partial pressure has significant effect in respiration rate at aerobic condition, but in ultra-low oxygen (ULO) condition its effect is not clear and more researches are needed.

Furthermore, the respiration rate influences the mass loss, because there are carbon losses. However, the major part of mass loss is in function of water vapor loss. Some authors reported that mass loss is an important contributor to the maintenance of high quality during postharvest in apples (MAGUIRE et al., 2000; BRACKMANN et al., 2007) and peaches

IDepartamento de Fitotecnia, Universidade Federal de Santa Maria (UFSM), 97105-900, Santa Maria, RS, Brasil. E-mail: auribrackmann@gmail.com. Autor para correspondência.

"Curso de Agronomia, UFSM, Santa Maria, RS, Brasil.

"IIPrograma de Pós-graduação em Agronomia, UFSM, Santa Maria, RS, Brasil.

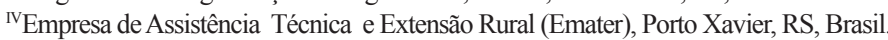

vEmater, Candelária, RS, Brasil 
(PINTO et al., 2012). However, these studies do not distinguish the effect of water loss and dioxide carbon losses on total mass loss and are not accompanied by the respiration ( $\mathrm{CO}_{2}$ production) and $\mathrm{O}_{2}$ uptake in real time throughout the controlled atmosphere storage period.

The objective of this research was to evaluate the effect of two different $\mathrm{CO}_{2}$ partial pressures associated to ULO storage, on the mass loss in function of respiration, oxygen uptake, respiratory rate and other variables of 'Fuyu' persimmons stored during 12 weeks in $\mathrm{CA}$ at $-0.5^{\circ} \mathrm{C}$.

The experimental material was obtained from a commercial orchard located in the city of Farroupilha, Rio Grande do Sul (Brazil), in 2012. At the harvest, the fruit showed $0.83 \mathrm{meq} 100 \mathrm{~mL}^{-}$ ${ }^{1}$ titratable acidity, soluble solids of $15.5{ }^{\circ}$ Brix, $1.21 \mathrm{~mL} \mathrm{CO}_{2} \mathrm{~kg}^{-1} \mathrm{~h}^{-1}$ respiration rate, $14.2 \mathrm{~mL} \mathrm{CO}_{2} \mathrm{~L}^{-1}$ internal $\mathrm{CO}_{2}$. The fruits were selected by eliminating injured fruit and were stored under two controlled atmosphere conditions: [1] $0.15 \mathrm{kPa}$ of $\mathrm{O}_{2}$ plus 2.0 $\mathrm{kPa}$ of $\mathrm{CO}_{2}$ and [2] $0.15 \mathrm{kPa}$ of $\mathrm{O}_{2}$ plus $6.0 \mathrm{kPa}$ of $\mathrm{CO}_{2}$ at the temperature of $-0,5^{\circ} \mathrm{C}$, during three months in chambers of $0.233 \mathrm{~m}^{3}$. The relative humidity in the chambers was maintained at $95 \%( \pm 1 \%)$.Completely randomized statistical scheme was used, with fourteen replications with ten fruits each.

The variables evaluated were: a) respiratory rate (evaluated by $\mathrm{CO}_{2}$ production during storage) and b) $\mathrm{O}_{2}$ uptake during storage, which were evaluated with a gas analyzer during all the days of storage, the results were expressed in $\mathrm{mL} \mathrm{CO}_{2} \mathrm{~kg}^{-1}$ $\mathrm{h}^{-1}$ and $\mathrm{mL} \mathrm{O}_{2} \mathrm{~kg}^{-1} \mathrm{~h}^{-1}$, respectively; c) respiration quotient: obtained by the quotient of $\mathrm{CO}_{2}$ production and $\mathrm{O}_{2}$ consumption $\left(\Delta \mathrm{CO}_{2} / \Delta \mathrm{O}_{2}\right)$; d) total mass loss: obtained by weighting the fruit before and after the storage. The data were expressed in percentage of the initial mass; e) mass loss in function of respiration: calculated by the relation between mass loss because of respiration, in function of $\mathrm{CO}_{2}$ accumulation in the chamber, and its contribution on total mass loss. Data expressed in percentage of total mass loss; f) mass loss in function of water vapor loss: obtained by subtraction between total mass loss and mass loss in function of respiration, data expressed in percentage of total mass loss; g) soluble solids: evaluated by refractometry from the juice of the samples, data expressed in ${ }^{\circ}$ Brix; h) titratable acidity: determined by titration of a solution of $10 \mathrm{~mL}$ fruit juice diluted in $100 \mathrm{~mL}$ of distillated water, with $\mathrm{NaOH} 0.1 \mathrm{~N}$. The results were expressed in meq $100 \mathrm{~mL}^{-1}$.

For each variable, was done a variance analysis (ANOVA), being the means submitted to regression analysis and Tukey test with 5\% of probability of error. The data expressed in percentage were transformed with the formula arc.sin $\left((\mathrm{x} / 100)^{0,5}\right)$ before submitted to variance analyses.

During storage, respiration rate was completely different on the two $\mathrm{CO}_{2}$ partial pressures (Figure 1A and 1D). On the lowest $\mathrm{CO}_{2}$ partial pressure $(2.0 \mathrm{kPa})$ the respiratory rate increased with the storage time. However, when fruit were stored in $6.0 \mathrm{kPa} \mathrm{CO}$ the respiration rate decreased with the storage time. These results indicated that the higher $\mathrm{CO}_{2}$ partial pressure reduced respiration even under ULO condition. The table 1 shows that the respiratory rate was lower in the higher $\mathrm{CO}_{2}$ level. This lower respiratory rate occurs because the $\mathrm{CO}_{2}$ is produced in tricarboxylic acid cycle, and the increase of partial pressure in the storage chamber reduced the $\mathrm{CO}_{2}$ production pathways (TAIZ \& ZEIGER, 2009). Another study demonstrated reduction in respiration with the increased of $\mathrm{CO}_{2}$ partial pressure (STEFFENS et al., 2007).

The $\mathrm{O}_{2}$ uptake was similar on both treatments, where occurs a linear decreasing during the storage time (Figure 1B and 1E), but fruit stored at $2.0 \mathrm{kPa} \mathrm{CO}_{2}$ have a higher angular coefficient $(-0.0105)$ than fruit stored at $6.0 \mathrm{kPa} \mathrm{CO}_{2}(-0.0049)$. The higher angular coefficient indicated that the fruit stored at $2.0 \mathrm{kPa} \mathrm{CO}$ showed a marked decreasing in $\mathrm{O}_{2}$ uptake during storage than fruit stored at $6.0 \mathrm{kPa}$ $\mathrm{CO}_{2}$. However, the total $\mathrm{O}_{2}$ uptake was significantly higher in fruit stored in the lowest $\mathrm{CO}_{2}$ partial pressure (Table 1).These decreasing in $\mathrm{O}_{2}$ uptake linked with increasing $\mathrm{CO}_{2}$ production throughout the storage, increased the respiratory quotient on the fruit stored at this condition $\left(2.0 \mathrm{kPa} \mathrm{CO}_{2}\right)$ (Figure 1C). Similar results were reported in apples (SAQUET \& STREIF, 2002). The result indicated that fruit stored at this $\mathrm{CO}_{2}$ level increased the anaerobic metabolism from the onset to the end of storage, because higher respiratory quotient values showed greater anaerobic metabolism (SAQUET \& STREIF, 2002). However, when fruits were stored in $6.0 \mathrm{kPaCO}$ the anaerobic metabolism on the beginning and end was the same, because the respiratory quotient was the same during storage time (Figure 1F). After three months of storage the average respiratory quotient was similar in both $\mathrm{CO}_{2}$ partial pressures (Table 1).

Some studies have suggested that higher mass loss can keep higher postharvest quality, because it increases the gas exchange in apples (BRACKMANN et al., 2007) and peaches (PINTO et al., 2012). However, not all mass loss increases the gas exchange in fruit, but only the mass loss as a 


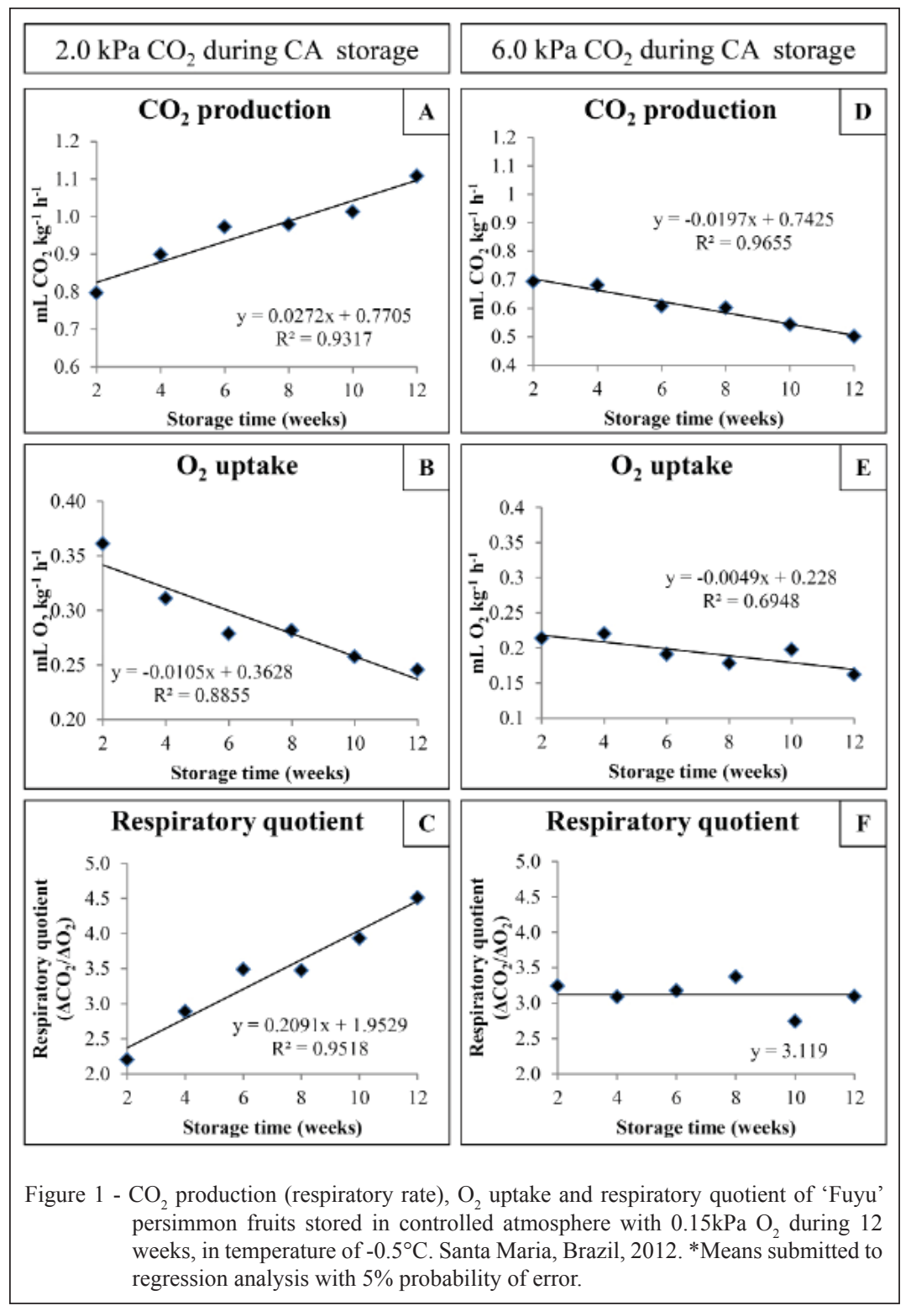

result of water vapor loss. At this study it was verified that the respiration have a significant effect on mass loss, being responsible for $24 \%$ of the total mass loss, and the result were similar than the obtained in apples stored at the same relative humidity, in which about $20 \%$ of mass is in function of respiration rate (MAGUIRE et al., 2000). The table 1 shows that the higher respiratory rate on fruit stored with $2.0 \mathrm{kPa}$ $\mathrm{CO}_{2}$ culminated in higher mass loss in function of respiration rate. Inverse result was obtained with $6.0 \mathrm{kPa} \mathrm{CO}$ in relation to mass loss resulted from water vapor losses. The total mass loss was higher in fruit stored with $2.0 \mathrm{kPaCO}_{2}$ as a result of the higher respiration rate of this treatment.
The higher respiratory rate and $\mathrm{O}_{2}$ uptake of fruit stored with $2.0 \mathrm{kPa}$ of $\mathrm{CO}_{2}$ (Table 1) result in chemical changes in fruit. Significant effect was verified in soluble solids contents, which showed a reduction in fruits stored with $2.0 \mathrm{kPa} \mathrm{CO}$. However, the soluble solids contents are higher on fruit submitted to $6.0 \mathrm{kPa}$ $\mathrm{CO}_{2}$ because there is higher mass loss in function of water vapor loss. Another studies showed that the mass loss as a result of water loss increased de accumulation of soluble solids during storage (BRACKMANN et al., 2004; BRACKMANN et al., 2007; PINTO et al., 2012). In general, the persimmon fruits have low acidity and its concentration does not change during the storage, and is not affected by the $\mathrm{CO}_{2}$ concentration (Table 1). 
Table 1 - Respiratory rate, oxygen uptake rate, respiratory quotient, mass loss in function of respiration, mass loss in function of water loss, soluble solids and titratable acidity in 'Fuyu' persimmon during 12 weeks in controlled atmosphere storage, means of all days of storage. Santa Maria, Brazil, 2012.

\begin{tabular}{|c|c|c|c|}
\hline \multirow{2}{*}{ Variable } & \multirow{2}{*}{----------Unit-------- } & \multicolumn{2}{|c|}{-----Controlled atmosphere $\left(\mathrm{O}_{2}+\mathrm{CO}_{2} \mathrm{kPa}\right)$} \\
\hline & & $0.15+2.0$ & $0.15+6.0$ \\
\hline Respiratory rate & $\mathrm{mLCO} \mathrm{Cg}^{-1} \mathrm{~h}^{-1}$ & $0.96 \mathrm{a} *$ & $0.60 \mathrm{~b}$ \\
\hline Oxygen uptake rate & $\mathrm{mL} \mathrm{O}_{2} \mathrm{~kg}^{-1} \mathrm{~h}^{-1}$ & $0.29 \mathrm{a}$ & $0.19 b$ \\
\hline Respiratory quotient & $\Delta \mathrm{CO}_{2} / \Delta \mathrm{O}_{2}$ & $3.42 \mathrm{a}$ & $3.11 \mathrm{a}$ \\
\hline Mass loss in function of respiration** & $\%$ & $24.07 \mathrm{a}$ & $20.97 b$ \\
\hline Mass loss in function of water loss $* *$ & $\%$ & $75.93 b$ & $79.03 \mathrm{a}$ \\
\hline Total mass loss of fruit & $\%$ & $1.85 \mathrm{a}$ & $1.34 \mathrm{~b}$ \\
\hline Soluble solids & ${ }^{\circ}$ Brix & $15.13 b$ & $16.06 \mathrm{a}$ \\
\hline Titratable acidity & meq $100 \mathrm{~mL}^{-1}$ & $0.63 \mathrm{a}$ & $0.64 \mathrm{a}$ \\
\hline
\end{tabular}

*Means followed by equal letters, in the line, do not differ by Tukey test, at $5 \%$ probability of error.

** Percentage of mass loss in relation of total mass loss of fruits.

In 'Fuyu' persimmon the total mass loss is significantly affected by controlled atmosphere storage conditions. $2.0 \mathrm{kPa} \mathrm{CO}$, promotes changes in respiratory quotient during storage time, keep higher mass loss in function of respiration $\left(\mathrm{CO}_{2}\right.$ losses $)$ and lower soluble solids after storage. Titratable acidity is not affected by the two $\mathrm{CO}_{2}$ partial pressures under ULO treatments.

\section{ACKNOWLEDGEMENTS}

To Conselho Nacional de Desenvolvimento Científico e Tecnológico, Coordenação de aperfeiçoamento de Pessoal e de Nível Superior and Fundação de Amparo à Pesquisa do Estado do Rio Grande do Sul, for financial support.

\section{REFERENCES}

BRACKMANN, A.et al. Regimes de atmosfera controlada para o armazenamento de caqui 'Kyoto'. Ciência Rural, v.34, n.5, p.1607-1609, 2004.Available from: $<$ http://www.scielo.br/pdf/cr/ v34n5/a44v34n5.pdf>. Accessed: Set. 17, 2012.

BRACKMANN, A. et al. Indução da perda de massa fresca e a ocorrência de distúrbios fisiológicos em maçãs 'Royal Gala' durante o armazenamento em atmosfera controlada. Revista Brasileira de Armazenamento, v.32, n.2, p.87-92, 2007.

BRACKMANN, A. et al. Manutenção da qualidade pós-colheita de maçãs 'Royal Gala' e 'Galaxy' sob armazenamento em atmosfera controlada. Ciência Rural, v.38, n.9, p.2478-2484, 2008. Available from: $<$ http://www.scielo.br/pdf/cr/v38n9/a10v38n9.pdf $>$. Accessed: Jun. 10, 2013.

MAGUIRE, K.M. et al. Harvest date, cultivar, orchard and tree effects on water vapor permanence in apples. Journal of the American Society of Horticultural Science, v.125, n.1, p.100-104, 2000.

PINTO, J.A.V. et al. Indução de perda de massa na qualidade pós-colheita de pêssegos 'Eragil' em armazenamento refrigerado. Ciência Rural, v.42, n.6, p.962-968, 2012.

SAQUET, A.A.; STREIF, J. Respiração e produção de etileno de maçãs armazenadas em diversas concentrações de oxigênio. Revista Brasileira de Agrociências, v.8, n.1, p.71-75, 2002.

STEFFENS, C.A. et al. Taxa respiratória de frutas de clima temperado. Pesquisa Agropecuária Brasileira, v.42, n.3, p.313-321, 2007.Available from: <http://www.scielo.br/pdf/pab/v42n3/03.pdf>. Accessed: Set.17, 2012.doi: 10.1590/S0100-204X2007000300003.

TAIZ, L.; ZEIGER, E. Fisiologia vegetal. 4.ed. Porto Alegre : Artmed, 2009. 848p. 